$\begin{array}{ll}\text { Dikumpulkan } & : 4 \text { Juli } 2019 \\ \text { Diterima } & : 15 \text { Agustus } 2019 \\ \text { DOI } & : \text { https://doi.org/10.22146/jpt.48834 }\end{array}$

\title{
Paradigma Historis Backpacking Travel Sebagai Perjalanan Wisata
}

\author{
Pitaya', Muhammad Baiquni' $^{2}$, Marsono 3 , Nopirin ${ }^{4}$ \\ 'Diploma Kepariwisataan, Sekolah Vokasi, Universitas Gadjah Mada \\ pitaya_p@ugm.ac.id \\ ${ }^{2}$ Departemen Geografi Pembangunan, Fakultas Geografi, Universitas Gadjah Mada \\ mbaiquni@ugm.ac.id \\ ${ }^{3}$ Departemen Sastra Nusantara, Fakultas Ilmu Budaya, Universitas Gadjah Mada \\ marsono@ugm.ac.id \\ ${ }^{4}$ Fakultas Ekonomika dan Bisnis, Universitas Gadjah Mada
}

\begin{abstract}
Nowadays backpacking travel is the most popular travelling style which famous to the youth traveller. According to the history, the travelling style can be tracked from the nomadic tribes in all corner of the world for their moving habit for run their life. Through the ages, the nomad who carries backpack at their back to bring necessities adopted by soldiers, explorers, and many kinds of travellers, until transformed to the modern free independent tourist (FIT) ; backpacker, flash packer to the present techno packer. The backpackers itself always become an interesting object for the scholars and the tourism experts. Their travelling style colorized every great journey that men ever made. This paper aim is to seek and identify the existence of backpackers and their travelling style throughout historical paradigm. The methods using in this research is both literatures studies and field observatory to the iconic backpacking travels sites in the history. The results show that the backpackers and backpacking travel consists of unique characteristics who determine their travelling style that different among the common tourist or even the group inclusive tour (GIT). The backpackers travels much longer, more far, they travel some time to the off beaten tracks, they always made interaction with the local community, and their journeys inspired others. No wonder if in the future backpacking travel will contributes so many influences to the tourism world.
\end{abstract}

Keywords: Historical Paradigm, Backpacker, Backpacking Travel 


\section{PENDAHULUAN}

Di era globalisasi yang semakin tidak tertahankan saat ini, dunia mengalami perubahan semakin cepat hampir di semua sektor akibat dari meningkatnya harga kebutuhan bahan bakar, semakin pentingnya posisi sosial media dan pesatnya perkembangan teknologi baru. Sehingga tidak mengherankan apabila faktor yang paling stabil pada kondisi ini adalah "perubahan" (Vaals, 2013). Dalam konteks pariwisata, industri ini tidak hanya merupakan sektor yang paling cepat dan paling besar berkembang di dunia, akan tetapi juga merupakan salah satu bidang pang paling tidak stabil sehingga karakter pariwisata modern didasarkan pada perubahan yang konstan (Majstorovic et al, 2013). Menilik pendapat tersebut, sangat menarik apa yang disampaikan oleh Cottrel (2001), yang memandang industri pariwisata sebagai bidang yang sangat sensitif terhadap resesi ekonomi di sisi permintaan, tensi politik di wilayah destinasi dan pengharapan konsumen. Meskipun tidak dapat dipungkiri bahwa industri pariwisata tersebut dikelilingi oleh berbagai macam ketidak-pastian akan tetapi perusahaan-perusahaan pariwisata lebih memilih fokus pada strategi jangka pendek selagi mengantisipasi skenario masa depan yang paling memungkinkan yang dapat memperkuat posisi mereka secara signifikan terhadap pasar di masa sekarang maupun di masa depan (ANVR dalam Vaals, 2013). Hal seperti ini umum terjadi karena secara alamiah pariwisata adalah suatu industri, dimana para pelakunya akan mencari keuntungan selagi mungkin dan berusaha untuk terus meningkatkan keuntungan tersebut dengan segala macam daya upaya yang ada karena industri pariwisata merupakan industri yang terus mengalami pergerakan, sesuai dengan filsafat pariwisata yang mengedepankan unsur mobilitas.

G. Deleuze dan F. Guattari dalam A Thousand Plateaus (1988) menginspirasi tentang filsafat mobilitas yang sering diistilahkan sebagai nomadologi atau ilmu pengetahuan mengenai pergerakan manusia dengan berbagai macam motif dan bentuknya, diantaranya yang paling populer adalah pariwisata. Sementara itu Tim Cresswell dalam On the Move (2006) mengutarakan bahwa dalam hal mobilitas terdapat tiga momen yang berhubungan yaitu; pertama mobilitas sebagai fakta yang secara potensial terobservasi dan terukur, suatu fakta empiris di mana terbukti dalam perencanaan transportasi dan teori migrasi. Yang kedua adalah mobilitas ditampilkan dalam berbagai macam model representasi seperti film, fotografi, literatur, filsafat, hukum dan lain sebagainya. Yang ketiga adalah momen mobilitas itu sendiri, dimana mobilitas tersebut dilakukan sebagai pengejawantahan pengalaman.

Perkembangan sektor pariwisata di tingkat dunia saat ini memang mengalami pertumbuhan yang luar biasa, kalau di tahun 1950-an jumlah wisatawan internasional yang melakukan pergerakan lintas negara hanya berjumlah kurang dari 50 juta wisatawan per tahun maka pada tahun 2012 jumlah wisatawan internasional telah melebihi 1 milyar orang (UNWTO, 2013). Lonjakan yang sangat luar biasa ini dapat ditemui di hampir semua belahan dunia, terutama di Eropa dan Amerika dimana liburan dan perjalanan wisata sudah membudaya sejak ratusan tahun yang lalu. Meskipun demikian, wilayah lain seperti Asia, Afrika dan Australia juga mengalami kenaikan yang cukup signifikan. 
\begin{tabular}{cr}
\multicolumn{2}{c}{ Secara umum pertumbuhan yang } \\
terjadi & memang sangat
\end{tabular} menggembirakan karena pariwisata telah menyumbang 9\% dari GDP dunia, 1 dari 11 pekerjaaan di dunia adalah terkait dengan pariwisata dan jumlah ekspor di sektor ini mencapai USD 1,3 trilyun, suatu jumlah yang fantastis. Tidak mengherankan apabila UNWTO sampai mengeluarkan kredo One Billion Tourists One Billion Opportunities dan berani memprediksikan untuk tahun 2030 nanti jumlah wisatawan yang melakukan pergerakan antar negara akan mencapai jumlah 1,8 milyar orang.

Cresswell (2006) menyampaikan tentang konsep mobilitas, dimana hal tersebut dianggapnya sebagai aspek fundamental dalam eksistensi geografis. Berkaitan dengan mobilitas pariwisata apabila ditinjau dari model perjalanannya, pergerakan wisatawan dari tahun ke tahun memiliki konsep yang serupa, mayoritas wisatawan masih mengandalkan paket-paket wisata yang di tawarkan oleh biro perjalanan sebagai media pesiar mereka. Tetapi seiring dengan kemajuan teknologi maka orang akan semakin mudah untuk merencanakan dan melaksanakan perjalanan wisatanya secara mandiri. Kalau di jaman dulu untuk membeli tiket pesawat, sesorang harus mengantri di outlet bandara atau harus datang ke kantor biro perjalanan, saat ini dengan semakin di optimalisasikannya kegunaan kartu kredit dan tersedianya layanan internet maka pembelian tiket pesawat dan wahana perjalanan lainnya dapat dilakukan secara daring. Demikian juga halnya dalam hal reservasi akomodasi di daerah tujuan wisata dan informasi terkini mengenai atraksi dan daya tarik wisata semuanya dapat di capai dengan "berselancar" di dunia maya. Berkembangnya portal penyedia jasa informasi elemen perjalanan wisata seperti agoda.com, booking.com, hotels.com, tripadvisor.com dan wikitravel.com ikut berperan dalam tumbuhnya para wisatawan mandiri.

Wisatawan mandiri yang dimaksud disini adalah seseorang yang melakukan perjalanan, baik sendiri maupun dengan orang lain tetapi tanpa mengikuti paket wisata berpemandu dan memilih menggunakan tas punggung daripada koper maupun jenis bagasi lainnya selama perjalanan mereka (Sicroff et al, 2003), istilah populer untuk menyebut jenis wisatawan ini adalah backpacker. Wisatawan ini biasanya sangat mengandalkan referensi buku panduan wisata (Lonely Planet, Eyewitness Travel, Frommer's), website dan pengalaman dari para pendahulu mereka dalam merencanakan perjalanan wisatanya.

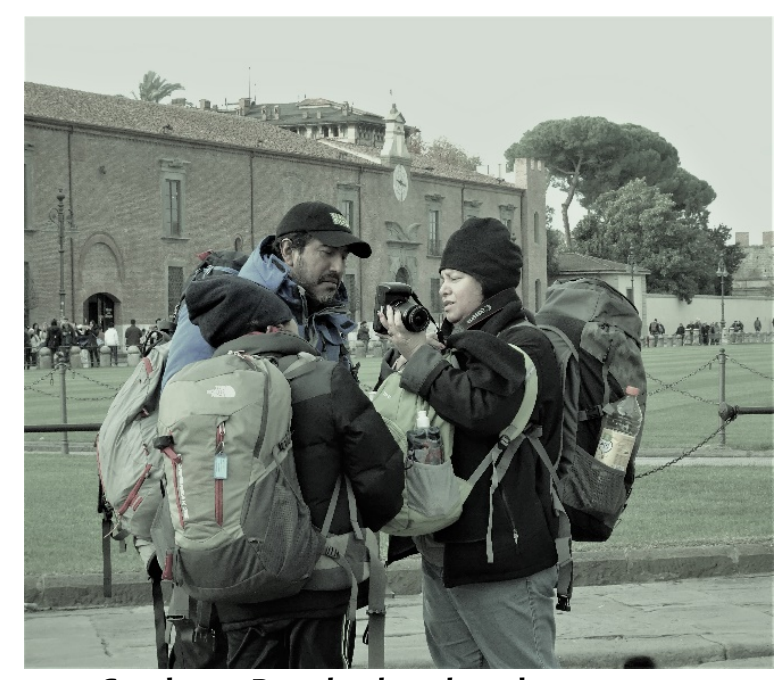

Gambar 1. Para backpacker, dengan tas punggung sebagai salah satu identitas mereka Sumber : Dokumentasi penulis

Karena para backpacker ini sangat umum memiliki komunitas-komunitas tersendiri, tidak hanya berdasarkan minat atau daerah asal saja akan tetapi juga berdasar pada destinasi wisata tertentu maka mereka sangat mudah berinteraksi satu sama lain dalam bertukar informasi. Informasi ini menjadi hal yang sangat penting untuk dibagi 
dan terus dimutakhirkan karena meskipun konsep backpacker adalah budget traveler atau wisatawan yang peka terhadap anggaran tetapi dalam perencanaan perjalanan biasanya mereka tetap menghadapi banyak sekali pilihan.

Kondisi dewasa ini yang terjadi adalah para calon konsumen memang sangat dimanjakan dengan adanya berbagai macam pilihan, yang terutama disesuaikan dengan anggaran yang mereka miliki atau hendak dihabiskan. Pilihan terkadang tidak hanya dua atau tiga tetapi menjadi suatu opsi yang sangat kompleks mengingat suatu destinasi wisata kadangkala menawarkan atraksi yang begitu beragam.

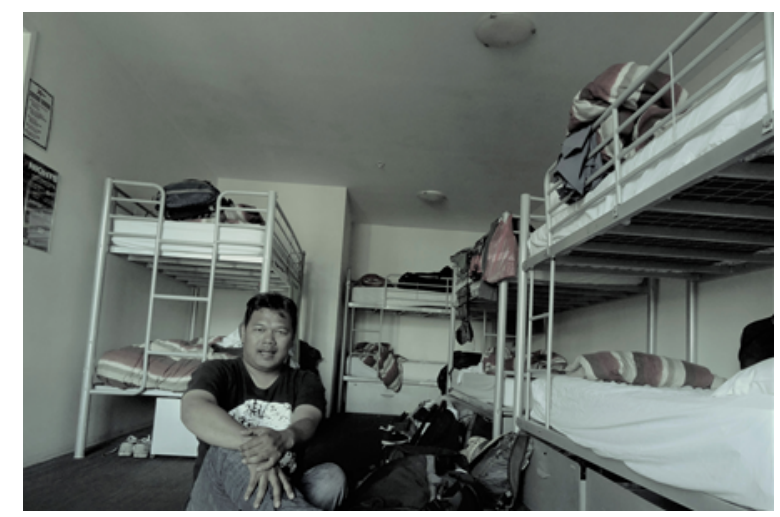

Gambar 2. Dormitory, tipe akomodasi yang populer digunakan oleh para backpacker dalam melakukan perjalanan wisata Sumber : Dokumentasi Penulis

Oleh karena itu, untuk menikmati daya tarik yang ada di sana wisatawan dalam perencanaannya harus memilih dan memutuskan jenis transportasi apa yang hendak dia pakai, hotel kelas apa yang hendak ia tinggali dan berbagai macam kebutuhan primer lainnya selama perjalanan wisata dari dan kembali ke negara asalnya.

Untuk moda transportasi udara saja misalnya, kalau dulu hanya tersedia full service airline, maka sekarang hampir setiap maskapai penerbangan flag carrier menambah lini perusahaannya dengan mengoperasikan juga low cost carrier, seperti Garuda Indonesia yang mengoperasikan Citilink. Belum lagi di tambah dengan semakin maraknya pertumbuhan maskapai penerbangan yang memang memposisikan dirinya sejak awal sebagai maskapai berbiaya rendah seperti Ryan Air, Scoot, Air Asia, Tiger Airways, Cebu Pacific, dan lain sebagainya.

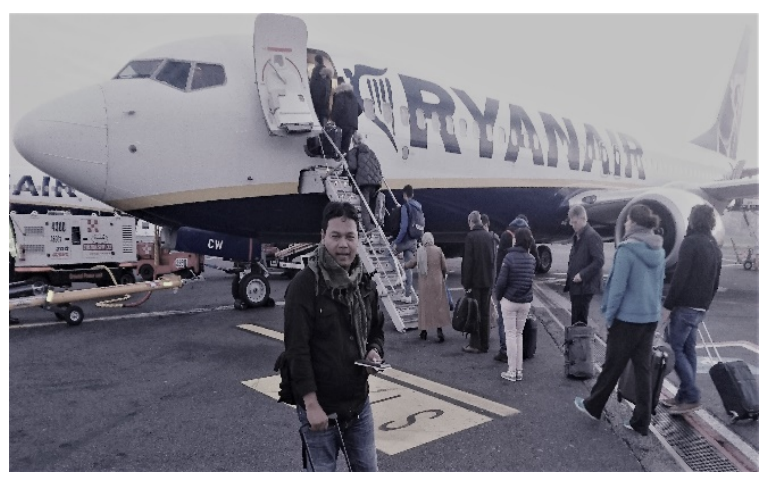

Gambar 3. Ryan Air, salah satu maskapai penerbangan berbiaya rendah yang turut berpengaruh dalam perkembangan backpacking travel

Sumber : Dokumentasi penulis

Para wisatawan mandiri atau backpacker ini semakin lama semakin banyak jumlahnya, pergerakannya pun semakin jauh, sehingga Berger \& Paris (2013) menyebutnya sebagai pionir dalam mobilitas, yang menyediakan bagian unik bagi penelitian kritis tentang pariwisata. Terlepas dari itu semua, satu hal pasti yang membuat backpacker dapat berkelana ke banyak wilayah adalah karena kemandirian dan keleluasaan yang mereka miliki, sesuatu yang tidak terdapat bagi mereka yang ikut paket wisata. Tidak heran banyak destinasi wisata baru ditemukan, dipopulerkan dan kemudian banyak dikunjungi orang akibat adanya kegiatan mereka. Ketika para ahli pariwisata menyampaikan gagasan mengenai ekowisata, wisata minat khusus, wisata petualangan, dark tourism, responsible 
tourism dan lain sebagainya, dalam hal ini para backpacker-lah yang mengimplementasikan teori tersebut di lapangan yang sebenarnya.

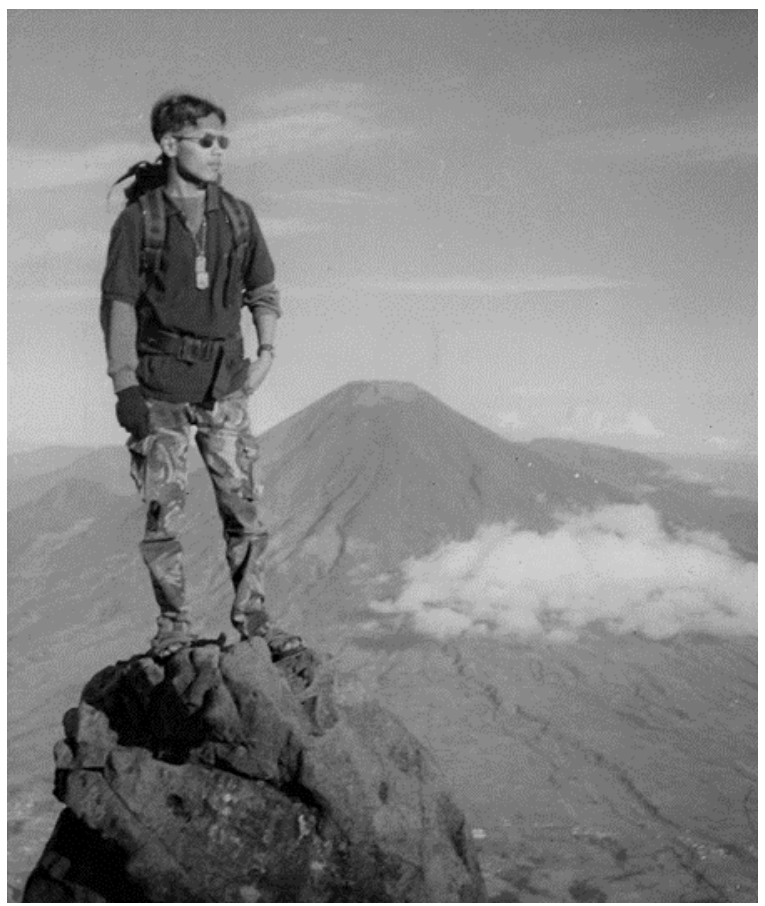

Gambar 4. Backpacker dalam petualangan di alam bebas

Sumber: Dokumentasi penulis

\section{METODE}

Mengingat sejarah backpacker dan backpacking travel telah berkembang begitu lama dan telah digambarkan oleh banyak peneliti selama beberapa dekade, maka metode dalam penelitian ini yang dipilih adalah menggunakan metode analisis deskriptif. Berbagai data sekunder yang dikumpulkan dari penelusuran jejak sejarah para backpacker melalui kajian literatur yang pernah ditulis oleh para pelaku perjalanan tersebut maupun oleh para ahli atau penulis yang telah terlebih dahulu menuliskan tentang eksistensi mereka di dunia pariwisata. Metode selanjutnya adalah melakukan observasi langsung ke tempat-tempat yang menjadi tonggak sejarah para pelaku backpacking travel, melakukan wawancara mendalam dengan backpacker yang ditemui dan selanjutnya data-data yang diperoleh dapat ditampilkan dalam bentuk gambar dokumentasi maupun narasi yang dapat mendeskripsikan perjalanan backpacking travel dari sudut pandang historis ; alur masa, identitas, karakteristik, dan perkembangannya.

\section{HASIL DAN PEMBAHASAN}

\section{A. Teori Backpacker}

Meskipun pada saat ini istilah backpacker merupakan hal yang sangat populer dalam konteks model perjalanan wisata, akan tetapi secara istilah "backpacker" baru dikenal dalam literatur-literatur mengenai pariwisata pada awal dasawarsa 1970-an (Majstorovic, 2011). Secara umum para ahli, akademisi, peneliti dan para pelaku pariwisata memahami istilah backpacker pada beberapa level, akan tetapi hingga saat ini belum terdapat definisi yang dapat diterima secara internasional (Hampton \& Hamzah, 2010).

Istilah-istilah yang pertama kali muncul pada awalnya cenderung relevan terhadap tipe-tipe hippies traveler pada akhir tahun 1960-an seperti istilah yang dikemukakan oleh Cohen (1973) yaitu "drifter" atau yang disebut oleh Vogt (1976) sebagai “wanderer". Sementara itu Riley (1988) memberikan istilah yang secara de facto sangat sesuai dengan esensi backpacker saat ini, yaitu "budget travellers", yang ia definisikan sebagai,

"Orang yang memiliki hasrat
untuk memperpanjang perjalanan
mereka lebih jauh dari liburan
pada umumnya dan memiliki
kepedulian terhadap anggaran
yang dihabiskan. Mereka berusaha
melepaskan diri dari kebuntuan
dan rutinitas setiap harinya yang
monoton, dari pekerjaan mereka,
dari membuat keputusan-


keputusan tentang karir mereka, serta hasrat untuk menunda pekerjaan, pernikahan maupun segala jenis tanggungjawab lainnya".

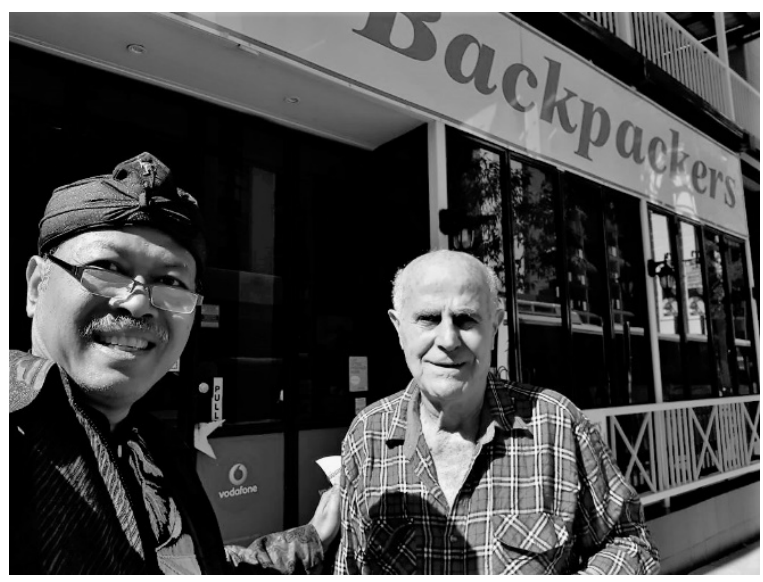

Gambar 5. Backpacker di Australia, negeri dimana istilah backpacker pertama kali digunakan dalam dunia akademis Sumber : Dokumentasi Penulis

Istilah backpacker secara akademis baru di bahas pertama kali oleh peneliti asal Australia, Philip Pearce pada tahun 1990 dalam makalah yang berjudul "The Backpacker Phenomenon: Preliminary Answers to Basic Questions". Dalam makalah tersebut disampaikan bahwa backpacking travel lebih merupakan pendekatan terhadap model perjalanan dan liburan daripada katagorisasi terhadap usia dan biaya yang dihabiskan. Sementara itu, backpacker adalah sebagai pelaku perjalanan (wisata) berbiaya rendah, terdiri dari anak-anak muda yang fenomenanya dapat diidentifikasi dalam lima kriteria, yaitu :

1. Pilihan terhadap moda akomodasi berbiaya rendah

2. Penekanan terhadap pertemuan dengan pelaku perjalanan yang lain

3. Terorganisir secara mandiri dan jadwal perjalanan yang fleksibel

4. Durasi perjalanan yang lebih lama daripada liburan pada umumnya
5. Penekanan terhadap hal-hal yang bersifat informal dan partisipasi pada kegiatan-kegiatan selama liburan.

Bradt (1995) menambahkan 5 kunci karakteristik pelaku perjalanan mandiri berpengalaman yang disebut sebagai "badges of honour" yaitu :

1. Bisa bertahan hanya dengan biaya kurang dari USD 15 per hari

2. Mengggunakan moda transportasi lokal

3. Membawa semua barangnya dengan ransel di punggung

4. Melakukan penawaran terhadap barang dan jasa selama perjalanan

5. Meninggalkan keriuhan dan kepadatan serta menemukan tempat-tempat baru

Setelah itu istilah backpacker mulai digunakan secara "resmi" untuk menyebut para pelaku perjalanan (wisatawan) mandiri seperti yang termuat dalam Government of Australia (1995), Loker-Murphy and Pearce (1995), Wilson (1997), Hampton (1998), Murphy (2000), Scheyvens (2002), Visser (2004), Richards and Wilson (2004), Teo and Leong (2006), Howard (2007), Rogerson (2007), Reichel et al (2009) dan oleh Pearce, Murphy dan Brymer (2009) ditambahkan tiga aspek paling krusial dalam menyebut backpacker, yaitu :

1. Usia di bawah 40 tahun

2. Memiliki jadwal perjalanan yang fleksibel, dan

3. Mendemonstrasikan keinginan yang kuat untuk turut serta dan berpartisipasi aktif dalam interaksi sosial selama liburan.

Istilah backpacker tersebut meskipun secara umum dikenal secara internasional untuk menyebut pelaku perjalanan (wisatawan) mandiri, akan tetapi di Amerika Serikat, sebagai salah satu negara yang maju dalam pariwisata, 
tidak menjadi istilah yang popular, karena istilah backpacker lazimnya digunakan untuk menyebut kegiatan berwisata dan berekreasi di alam bebas (Hannam, Ateljevic, 2008). Sehingga istilah backpacker mungkin saja memiliki pemahaman yang berbeda-beda, bukan hanya berdasarkan pendapat para ahli tetapi juga pemahaman umum yang berlaku di masing-masing negara.

Eric Cohen dalam Majstorovic et al (2013) menyampaikan bahwa definisi backpacker pada saat ini secara umum didasarkan pada penelitian pemasaran kuantitatif,

"mereka (backpacker) memilih
untuk tinggal di tempat
akomodasi yang berbiaya rendah,
mereka menghabiskan waktu
untuk berkelana jauh lebih banyak
daripada kebnayakan wisatawan,
dan mereka menikmati interaksi
bersama orang-orang, baik
masyarakat lokal maupun sesama
wisatawan lainnya".

Selanjutnya Majstorovic et al (2013) memberikan identitas tentang 5 pilar idiologi backpacker, yaitu :

1. Melakukan perjalanan dengan biaya rendah

2. Bertemu orang-orang yang berbeda

3. Menjadi atau merasakan kebebasan, mandiri, berpikiran terbuka

4. Mengorganisir setiap perjalanan secara individual dan mandiri

5. Melakukan perjalanan sejauh yang dimungkinkan (Welk, 2004)

Fenomena backpacker sebagai metafora dari mobilitas dalam konteks modern merupakan jalan hidup dan perjalanan, sekaligus merupakan ekspresi identitas. Backpacker merupakan metafora dari pariwisata modern, dan bahkan metafora dari generasi muda modern. Salah satu karakteristik dari perjalanan ala backpacker adalah eksplorasi, penelitian dan identifikasi terhadap destinasidestinasi baru sekaligus terhadap para pelaku kegiatan tersebut. Selama bertahun-tahun infrastruktur untuk melakukan kegiatan tersebut semakin baik, sempurna dan semakin terinstitusi sehingga semakin sulit untuk mengetahui dimana trend utama wisatawan berakhir dan dimana perjalanan ala backpacker dimulai (Richards, Wilson, 2004), dimana hal ini sangat sesuai dengan pendapat Clifford (1997) yang menyampaikan bahwa perjalanan merupakan bagian integral dari "new world order of mobility" di jaman modern.

Seiring perkembangan waktu dimana kemajuan teknologi semakin pesat, Cochrane (2005) mengenalkan konsep "backpacker plus" yaitu wisatawan mandiri yang memiliki tingkat kesejahteraan berlebih, mereka yang melakukan perjalanan wisatanya secara individual, independen akan tetapi tidak selalu bergantung pada pembiayaan yang rendah terhadap barang dan jasa selama berwisata. Konsep yang disampaikan ahli dari Universitas Leeds, Inggris ini sangat relevan dengan tentang "flashpacker" yang dikemukakan oleh Bleach and Schofield (2004) tentang wisatawan mandiri a la backpacker akan tetapi tidak keberatan untuk membayar barang dan jasa dengan harga tinggi di destinasi wisata serta mengedepankan gaya perjalanan yang berbeda, peduli pada mode dan pemanfaatan maksimal terhadap gawai modern.

Bagaimanapun pariwisata
modern ditandai dengan karakter
tumbuhnya bentuk dan jenis baru dari
pariwisata. Bukan lagi wisata


kontemporer dengan tujuan mencari $3 \mathrm{~S}$ (Sea, Sand and Sun) tetapi suatu kegiatan-kegiatan yang bervariasi selama perjalanan dan mengedepankan pengalaman perjalanan wisata yang otentik. Backpacking travel merupakan kebalikan total dari wisata massal (Majstorovic, 2013).

Berdasarkan berbagai pendapat para ahli tersebut dapat disimpulkan suatu definisi sederhana tentang backpacker sebagai wisatawan yang melakukan perjalanan dengan tas punggung, yang bertahan hidup dengan perhatian terhadap biaya yang dikeluarkan, dan pada umumnya melakukan perjalanan lebih jauh serta lebih lama daripada periode liburan yang konvensional.

\section{B. Sejarah Backpacking Travel}

Ditinjau dari sisi etimologi backpack berarti tas atau wadah yang ditempatkan di punggung. Adapun backpacking travel berarti perjalanan dengan menggunakan tas punggung tersebut sebagai wadah utama dalam memuat berbagai macam keperluan selama perjalanan. Istilah backpacker mengacu pada orangnya, mereka yang melakukan perjalanan dengan konsep backpacking.

Catatan sejarah menunjukkan bahwa yang disebut dengan backpacking travel atau perjalanan dengan memanfaatkan tas atau wadah yang ditempatkan di bagian punggung sudah dapat ditelusuri sejarahnya sejak ribuan tahun yang lalu. Bahkan, hingga saat ini masih terdapat suku-suku tradisional yang memakai ransel dengan bahan sama dengan yang dipakai oleh nenek moyang mereka. Pada awalnya para suku-suku nomaden yang tersebar di segala penjuru dunia melakukan perjalanan dari satu tempat ke tempat lain dengan tujuan mencari penghidupan yang lebih baik atau mereka berpindah dari satu tempat ke tempat lain demi menghindari bencana alam, serangan binatang buas maupun mendekati sumber makanan mereka, seperti halnya suku-suku Indian di Amerika Utara yang di masa lalu selalu tinggal tidak jauh dari tempat dimana kawanan Bison merumput.

Penemuan mumi Otzi "si manusia es" oleh dua orang backpacker asal Jerman Helmut dan Erika Simon di pegunungan Alpen antara Austria-Italia pada tanggal 19 September 1991 menunjukkan bukti konkrit bahwa suku nomaden di jaman pra sejarah telah menggunakan ransel primitif yang terbuat dari kulit binatang dan rangka dari kayu untuk menunjang kegiatan perjalanan mereka maupun dalam kehidupan sehari-hari. Penelitian para ahli menunjukkan bahwa Otzi hidup sekitar 3400 atau 3100 tahun sebelum masehi. Adanya penemuan mumi beserta perlengkapan perjalanannya tersebut maka Otzi sering disebut sebagai backpacker pertama di muka bumi.

Dalam perkembangan selanjutnya, sesuai dengan pola pikir dan kebutuhan manusia yang berkembang mengikuti perubahan jaman, perjalanan dengan tas punggung ini lambat laun berubah. Kalau sebelumnya para sukusuku nomaden bergerak dari satu tempat ke tempat lain, murni untuk mempertahankan hidup, pada masamasa selanjutnya perjalanan dilakukan dengan berbagai motivasi, terutama adalah untuk mencari pengalaman di dunia baru. Peristiwa inilah yang kemudian dikenal dengan era penjelajahan dunia. 


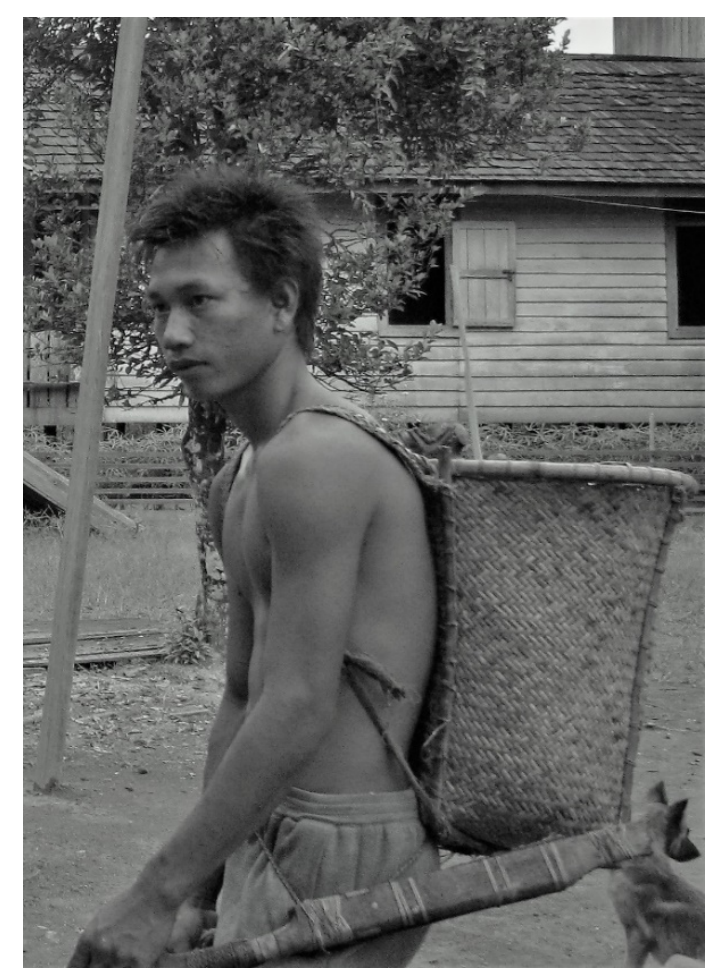

Gambar 6. Suku nomaden, sering dianggap sebagai backpacker pertama Sumber : Dokumentasi Penulis

Penjelajahan dunia pertama-tama yang tercatat dalam sejarah adalah perjalanan yang dilakukan oleh Antipatros Sidonius (Antipater dari Sidon), Philo Mechanicus, Strabo, Herodotus dan Diodorus Sicilius sekitar abad ke 2 sebelum Masehi dimana pengalaman mereka tertuang dalam antologi-puisi yang mengisahkan tentang 7 keajaiban dunia pada masa itu. Ketujuh keajaiban yaitu Taman Bergantung di Babilonia, Kuil Artemis di Ephesus, Mausoleum di Halicarnasus, Patung Colossus di Rhodes, Patung Zeus di Olympia, Mercusuar di Alexandria dan Piramida Besar di Giza. Kecuali keajaiban yang terakhir, semuanya sudah hilang dalam perjalanan sejarah, bahkan bekasbekasnya pun sulit ditemukan pada saat ini.

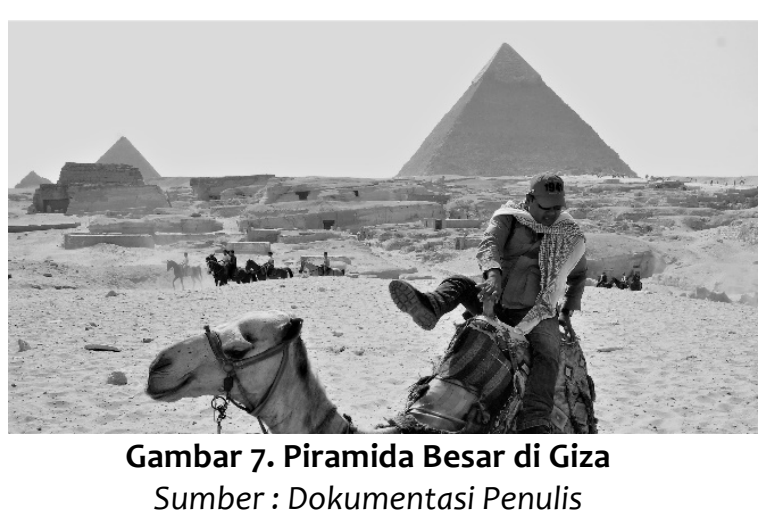

Sesuatu hal yang pasti dari perjalanan para penjelajah tersebut adalah mereka mampu menginspirasi begitu banyak orang dari berbagai bangsa untuk melakukan perjalananperjalanan mencari pengalaman baru ke tempat yang jauh dari tempat tinggalnya dalam kurun waktu ribuan tahun lamanya. Begitu banyak ekspedisi pribadi maupun dalam konteks resmi tugas negara dilakukan setelahnya. Sebutlah apa yang dilakukan umat Nasrani dari berbagai penjuru Eropa yang berusaha berziarah ke Yerusalem. Demikian juga dengan umat Islam yang berziarah ke Mekkah dan Madinah.

Adapun di Cina, tertulis dalam sejarah bagaimana pendeta Budha, I Cing yang berkelana menuju India untuk mendapatkan kitab suci dalam bahasa Sansekerta hingga pengembaraannya menuju Sriwijaya dan Jawa pada sekitar abad ke 7 Masehi. Tercatat juga perjalanan seorang pendeta Tao bernama Kiu Chang Chun dalam menemui Jenghis Khan pada awal abad ke 13 (Canning, 1968). Perjalanan Marco Polo dari Italia ke Cina melalui Jalur Sutera pada abad ke 13 untuk mendekatkan hubungan antara Dunia Barat dan Timur juga merupakan serangkaian perjalanan backpacking yang sangat monumental.

Pada abad pertengahan, dimana semangat penjelajahan dunia baru sangat kuat menginspirasi bangsa Eropa, 
tercatatlah masa pelayaran untuk menemukan bagian-bagian yang belum ditemukan dari peta dunia (hingga abad ke 15 , peta paling barat dari dunia yang dikenal orang Eropa hanya sampai ke Kepulauan (anary di Spanyol). Banyak pelaut Eropa berlayar menyeberangi Samudera Atlantik dan Pasifik untuk menemukan benua baru. Motivasi pelaut masa itu bukan lagi sekedar mendapatkan pengalaman baru, akan tetapi juga implementasi dari dogma $3 \mathrm{G}$ (Gold, Glory, Gospel), yaitu mencari harta kekayaan, kemuliaan dan menyebarkan agama Nasrani. Selama pelayaranpelayaran tersebut banyak sekali ditemukan hal-hal baru, tidak hanya sekedar daratan atau tanah tak bertuan tetapi juga berbagai ilmu pengetahuan dan teknologi hingga pembuktian teori Bumi adalah Bulat yang diutarakan Galileo Galilei.

Namun di sisi lain, akibat penemuan dunia baru tersebut juga berimbas pada keserakahan umat manusia, dimana kolonialisme semakin berkembang pesat. Perjalanan backpacking yang awalnya memiliki kecenderungan positif beralih menjadi perjalanan yang penuh ketamakan bercirikan penaklukan suatu bangsa oleh bangsa lainnya. Penemuan gugusan kepulauan di Benua Amerika oleh Christopher Columbus pada tahun 1496 yang diikuti oleh Amerigo Vespucci pada tahun 1503 justru menjadikan benua baru tersebut menjadi ajang ekspedisi penaklukan yang kejam seperti tampak dalam serbuan Hernando Cortez ke Meksiko pada tahun 1518 dan Fransisco Pizarro ke Peru pada tahun 1532, dalam dua serangan tersebut dua bangsa asli Amerika, Aztec dan Inca dihancurkan beserta kebudayaannya.

Ketika era conquistadores (para penakluk) mulai berakhir pada abad ke 17. Giovanni Fransisco Gemelli Careri
(1651-1725) dari Italia melakukan perjalanan backpacking keliling dunia. Karena sadar bahwa perjalanannya membutuhkan banyak biaya maka ia berusaha melakukan perjalanan sembari berdagang dengan cara membeli barang di suatu tempat yang memiliki nilai ekonomis jauh lebih tinggi di tempat yang akan ia kunjungi berikutnya.

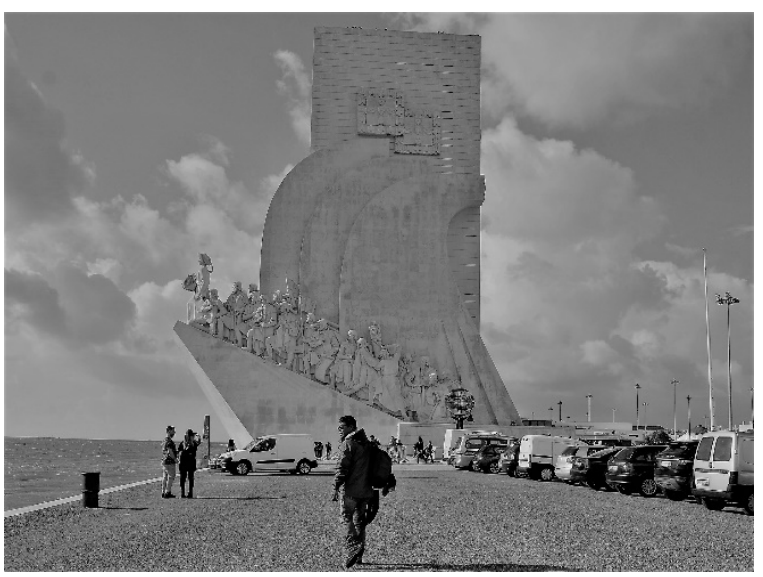

Gambar 8. Backpacker dengan latar belakang monumen penjelajahan dunia di Lisbon, Portugal

Sumber : Dokumentasi Penulis

Apabila para penjelajah kuno angkatan Antipatros Sidonius merangkum pegalamannya dalam bentuk puisi, maka Giovanni Cereri mempublikasikannya dalam bentuk buku. Diantaranya adalah Relazione delle Campagne d'Ungherria (1689), Viaggi in Europa (1692), dan Girro del Mondo (1699). Buku-buku tulisan Giovanni Cereri sangat inspiratif, tidak hanya bercerita tentang perjalanan dan objek wisata serta pengelamannya saja akan tetapi juga cara-cara untuk bertahan hidup selama perjalanan yang memakan waktu tidak sedikit itu. Buku Girro del Mondo atau Perjalanan Keliling Dunia yang terdiri dari 6 bagian, merupakan buku Cereri yang paling sukses hingga pada tahun 1704 diterjemahkan dalam bahasa Inggris dengan judul Voyage Round the World dan dalam bahasa Perancis dalam judul Voyage du Tour du Monde pada 
tahun 1719. Sejarawan sering menyebut Traveler kelahiran Taurianova ini sebagai backpacker modern pertama di dunia.

Pada masa itu, perjalanan backpacker seolah menjadi budaya di negara-negara Eropa, terutama Inggris yang mengenalkan konsep Grand Tour, suatu perjalanan wisata keliling Eropa yang sudah memiliki standard iteneray, sehingga bagi mereka yang merencanakannya tidak akan menemukan kesulitan berarti. Grand Tour ini begitu popular di kalangan para pemuda bangsawan Eropa, sehingga di anggap sebagai salah satu inisiasi menuju proses kedewasaan.

Dalam

perkembangan selanjutnya, tidak hanya kaum bangsawan saja yang melakukannya, tetapi juga para pemuda penganut protestan dari wilayah Eropa Utara dan Skandinavia turut meramaikan kegiatan wisata ini. Bahkan di awal abad ke 19 banyak para backpacker dari Amerika Serikat datang ke Eropa untuk merasakan pengalaman baru dalam perjalanan Grand Tour. Karakter Grand Tour yang pada awalnya khas bangsawan lambat laun menjadi lebih merakyat sampai akhirnya perjalanan ini menjadi sangat populer dan umum dilakukan oleh masyarakat kebanyakan.

Adanya kemajuan transportasi publik seperti kereta api pada tahun 1844 semakin mengukuhkan fenomena ini. Satu perjalanan Grand Tour yang paling terkenal adalah yang dilakukan oleh seorang novelis Inggris, William Thomas Beckford (1760-1844) yang mengabadikan perjalanannya dalam bentuk buku berjudul Letter of Italy with Sketches of Spain and Portugal yang diterbitkan pada tahun 1835. Buku tersebut cukup menginspirasi pada dekade-dekade berikutnya sebagai catatan perjalanan yang cukup rinci.
Akhir abad 18 hingga awal abad ke 19 juga ditandai dengan munculnya para eksplorer, mereka yang tertantang untuk melakukan petualangan di alam bebas, membuktikan teori yang terdapat dalam peta dunia. Kalau dulu konsep bumi adalah bulat sudah dibuktikan oleh para pelaut Portugis pimpinan Ferdinand Magellan dan Juan Sebastian Elcano pada tahun 1522, para eksplorer ini mencari tantangan lain. Ada yang berusaha menyusuri sungai terpanjang, mendaki gunung tertinggi, merambah hutan terlebat maupun mengarungi padang pasir terluas. Tidak jarang para eksplorer ini menempuh jalur yang pada masa itu mungkin hanya sekedar legenda atau cerita rakyat belaka. Kisah Sir Alexander Mackenzie yang berhasil melintasi daratan Kanada dari barat hingga ke timur di pesisir Samudera Pasifik pada tahun 1793 adalah salah satu contohnya. Relik dari perjalanan eksplorer bangsa Skotlandia ini bahkan masih bisa ditemui pada masa sekarang.

Pada masa Ratu Victoria memerintah Inggris (1837-1901), Britania Raya menjadi imperium terbesar di dunia sehingga bagian wilayahnya yang belum terekspos masyarakat luas menjadi sasaran para petualang untuk melakukan ekspedisi, terutama di benua Afrika dan Australia. Semangat backpacker pada masa ini cenderung eksplorasi untuk kepentingan ilmu pengetahuan dibandingkan upaya penaklukan seperti beberapa abad sebelumnya atau sekedar perjalanan wisata seperti yang banyak dilakukan di daratan Eropa. Dr. David Livingstone (1813-1873), seorang medismisionaris berkebangsaan Skotlandia membuka jendela baru dalam sejarah backpacking terutama yang berkaitan dengan petualangan di alam bebas. Pengembaraannya menjelajah pedalaman Afrika memberikan banyak sumbangan dalam ilmu geografi dengan 
disebarluaskannya landmark Afrika seperti danau Mweru, Ngami, Malawi, Bangweulu dan Tanganyika hingga Air Terjun Victoria di perbatasan Zambia dan Zimbabwe yang sangat fenomenal itu. Dunia internasional kemudian mengenal Dr. David Livingstone sebagai Penemu Benua Afrika.

Memasuki abad ke 20 kegiatan perjalanan dengan metode backpacking sempat tergeser oleh semakin berkembangnya pariwisata antar negara yang menggunakan kapal pesiar. Popularitas perjalanan wisata yang mengutamakan kenyamanan, kemewahan dan keanggunan khas bangsawan kembali menjadi gaya hidup di Eropa. Namun di sisi lain, para eksplorer, meskipun jumlahnya sedikit berusaha mencari pengalaman baru di belahan dunia yang masih jarang dikunjungi orang justru berusaha memperkuat eksistensi mereka.

Terdapat beberapa ekspedisi luar biasa di awal abad ke 20, dua diantarnya yang menjadi bahan kajian publik adalah Ekspedisi Kutub Utara yang dipimpin oleh Robert Edwin Peary pada tahun 1909 dan Ekspedisi Kutub Selatan yang dipimpin oleh Roald Amundsen antara tahun 1910-1912. Ekspedisi-ekspedisi tersebut bahkan memuat cerita kompetisi antar para eksplorer dan diakhiri dengan kisah tragis ketika para penakluk kutub tersebut harus kehilangan nyawa dalam petualangannya. Masyarakat dunia sadar bahwa adventure travel adalah kegiatan yang sangat beresiko, sehingga masamasa setelahnya segala sesuatu mengenai keselamatan, mulai dari peralatan yang digunakan sampai rute yang ditempuh diperhitungkan dengan matang. Kemajuan teknologi juga turut membantu mengenai masalah ini, karena dengan ditemukannya beraneka serat sintetis maka banyak peralatan baru untuk bertualang yang dapat dibuat lebih baik, lebih ringan dan lebih kuat.

Dua dekade pertama abad 20 memang merupakan masa penuh fenomena yang sangat mencengangkan ditilik dari sisi perkembangan teknologi. Banyak penemuan baru yang sangat berguna bagi umat manusia dirintis pada masa ini, terutama moda transportasi yang sebelumnya tidak pernah terbayangkan, yaitu dikembangkannya pesawat terbang. Kalau pada abad sebelumnya manusia hanya bisa mengangkasa dengan balon hidrogen yang secara teori adalah wahana yang lebih ringan dari udara, maka pesawat terbang adalah suatu lompatan teknologi karena manusia dapat menciptakan alat transportasi yang dengan kemajuan ilmu aerodinamika memungkinkan suatu wahana yang lebih berat dari udara.

Setelah berakhirnya Perang Dunia I pada tahun 1919, banyak pihak mulai berpikir untuk memanfaatkan teknologi penerbangan di masa perang agar dapat dipakai di masa damai yaitu dengan adanya maskapai penerbangan udara. Dengan adanya pesawat ini maka perjalanan backpacking ke tempat yang jauh sangat mungkin dilakukan dan sangat menghemat waktu. Tidak mengherankan apabila kemudian lebih banyak pelosok dunia yang kemudian dapat dijangkau oleh para petualang. Kalau sebelumnya perjalanan yang banyak dilakukan adalah di Eropa, maka selanjutnya perjalanan banyak juga dilakukan di Asia. Karena biaya yang dikeluarkan jelas lebih murah, maka para petualang ini dapat tinggal lebih lama di tempat tujuannya, dan efeknya segera terasa; mereka dapat menjangkau tempat-tempat yang sangat terpencil.

Banyak tempat yang ditemukan dalam petualangan para eksplorer backpacker itu kemudian berkembang 
menjadi destinasi wisata yang sangat populer di seluruh dunia. Air terjun Victoria saat ini merupakan atraksi andalan bagi pariwisata Zambia dan Zimbabwe, situs Machu Pichu yang ditemukan Hiram Bingham III pada tahun 1912 menjadi destinasi wisata utama di negara Peru, demikian juga dengan pesona air terjun St. Angel yang di eksplorasi Jimmie Angel pada tahun 1937 berkembang menjadi daya tarik wisata utama Venezuela. Di luar segala cerita petualangan yang penuh heroisme dan romantika, ada juga hal unik dan terasa konyol dalam perkembangan dunia backpacking ini, yaitu ekspedisi dari Jerman ke Pegunungan Himalaya pada tahun 1938-1939.

Ketika Adolf Hitler menjadi fuhrer (pemimpin) Jerman pada tahun 1934, ia memiliki konsep superioritas Jerman yang diyakininya berasal dari inti bangsa Arya. Untuk mendukung keyakinannya tersebut ia memerlukan bukti-bukti ilmiah, dan meskipun dasar pemikirannya adalah rasisme karena ia percaya bahwa bangsa Jerman dengan ras Arya-nya memiliki kasta yang lebih tinggi dan ditakdirkan untuk memimpin bangsa-bangsa lain di dunia, ia mendapat dukungan dari mayoritas rakyat Jerman. Karena hal itulah Sang Fuhrer mengirim serangkaian ekspedisi ke Pegunungan Himalaya, berdasarkan asumsi bahwa Bangsa Arya yang hilang saat masa Atlantis berakhir terdapat beberapa yang selamat dan bermukim di wilayah perbatasan India dan Cina itu. Meskipun ekspedisi yang dilakukan oleh Peter Aufscheneiter dan Ernst Schafer dikamuflasekan sebagai ekspedisi ilmiah, namun karena kedoknya mudah sekali terbongkar, apa yang dilakukan oleh para petualang Jerman itu disambut dengan sinisme yang meluas di Eropa. Bahkan kegiatan backpacking keliling Jerman yang diwajibkan untuk para anggota Pemuda Hitler (Hitlerjugend) yang juga memuat pembekalan patriotisme dan nasionalisme mendapat banyak kecaman dari banyak pihak karena seharusnya backpacking tidak masuk dalam ranah indoktrinasi politik.

\section{Hippies dan Backpacking Travel}

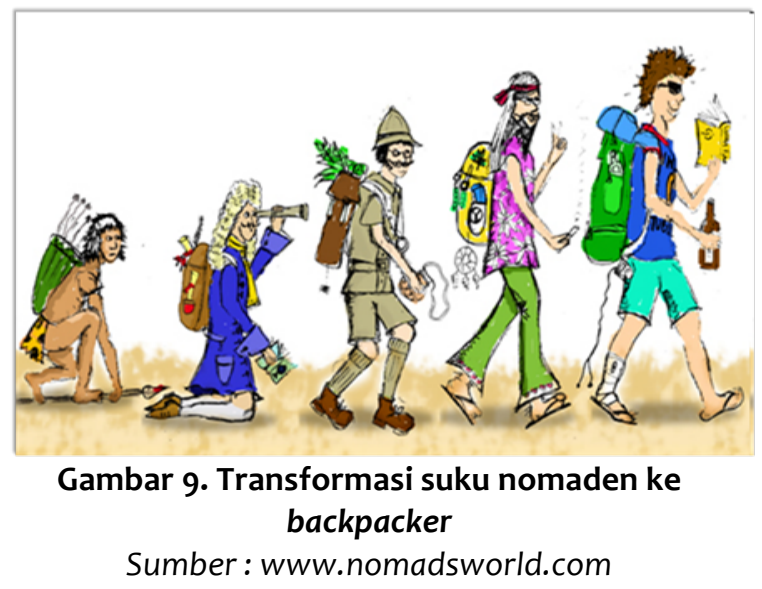

Sewaktu perusahaan maskapai penerbangan British Overseas Airways Corporation (BOAC) dari Inggris mengenalkan jalur penerbangan lintas Atlantik dengan pesawat De Havilland Comet pada 4 Oktober 1958, dimana saat itu dapat menghemat perjalanan dari London ke New York yang semula 6 hari dengan kapal laut menjadi 6 jam saja, backpacking mulai berubah menjadi bisnis. Hal ini terjadi karena banyak orang ingin merasakan perjalanan ala backpacking tetapi mereka hanya memiliki waktu yang singkat saja, sehingga banyak beberapa hal mulai di buat instan. Misalnya untuk berkelana dari Inggris ke Amerika Serikat dan dilanjutkan ke bagian-bagian negara yang jumlahnya 50 itu semuanya dilakukan dengan menumpang pesawat terbang. Para backpacker menggunakan kendaraan darat hanya secara lokal saja, mereka mengelola waktu sebaik mungkin agar dapat berkunjung ke banyak destinasi maupun melihat atraksi wisata dalam tempo yang singkat. 
Beberapa biro perjalanan bahkan membuat paket wisata untuk kegiatan backpacking ini dan akomodasi khusus backpacker berkembang pesat di Amerika Serikat.

Dekade 1950-an juga diwarnai dengan konflik bersenjata di beberapa tempat di dunia, dua yang paling berpengaruh adalah Perang Korea dan Perang Indo China dimana dalam konflik tersebut banyak kekuatan Eropa dan Amerika terlibat secara intensif. Bagi sebagian kalangan yang tidak bisa menerima alasan negaranya terlibat dalam perang terbuka dan masih trauma dengan akibat yang ditinggalkan selama berlangsungnya Perang Dunia II yang belum lama berakhir mendorong timbulnya golongan baru yaitu kaum Hippies. Mereka adalah anak-anak muda yang sangat mendambakan kebebasan, dan karena budaya anti kemapanan tersebut juga di di dukung beberapa golongan intelektual sekaligus bermodal, gaya hippies mendapatkan tempat tersendiri di kalangan generasi muda Eropa dan Amerika.

Salah satu hal yang dilakukan kaum hippies adalah melakukan perjalanan backpacking. Berbeda dengan petualangan-petualangan terdahulu yang sangat mengandalkan moda transportasi umum, para hippies ini banyak melakukan perjalananya dengan kendaraan pribadi yang di cat warnawarni sesuai budaya mereka. Pakaian nyentrik dengan motif bunga-bunga, celana berujung lebar, rambut panjang dan cambang lebat ditambah dengan kebiasaan menghisap marijuana menjadi hal yang melekat pada masa ini.

Kegiatan plesiran kaum hippies yang masih terbatas di Eropa segera di tangkap sebagai suatu kesempatan bisnis bagi para pengusaha yang kemudian menyediakan media transportasi jarak jauh lintas benua yang tidak terpikirkan sebelumnya yaitu dengan bus. Perusahaan bus pertama yang melayani bacpaking antar benua adalah Indiaman dari Inggris pada tahun 1957 yang diikuti oleh Swagman Tour. Rute perjalanan darat ini menempuh jarak lebih dari $10.000 \mathrm{~km}$, dari London di Inggris hingga Madras di pantai timur India.

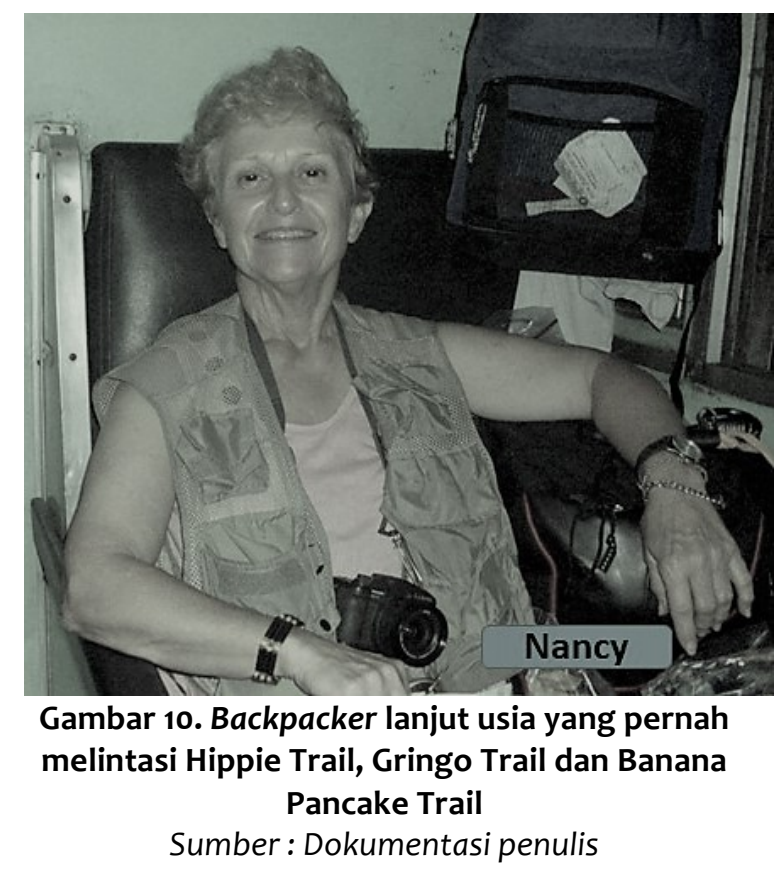

Perjalanan selama lebih dari 3 bulan ini melintasi London (Inggris) Channel (Perancis) - Brussel (Belgia) Lucerne (Swiss) - Milan (Italia) - Zagreb (Kroasia) - Beograd (Yugoslavia) -Sofia (Bulgaria) - Istanbul - Ankara - Adana (Turki) - Beirut (Libanon) - Damaskus (Suriah) - Petra (Yordania) - Baghdad (Iraq) - Teheran - Ishafan - Persepolis (Iran) - Zamedan (Afghanistan) - Quetta (Pakistan) - Khyber Pass - Lahore - New Delhi - Agra - Madras (India). Total terdapat 17 negara yang dikunjungi dalam perjalanan ini dan tentu saja menawarkan pengalaman yang luar biasa bagi mereka yang mengikutinya. Selama lebih dari dua dekade rute perjalanan yang kemudian disebut Hippie 
Trail ini begitu mempesona para anak muda di Eropa untuk mencobanya.

Kaum hippies di daratan Amerika mencapai puncak kegiatannya pada saat berkecamuknya Perang Vietnam. Selain menggelar banyak aksi protes mengutuk keterlibatan negaranya dalam perang yang berlangsung selama hampir sepuluh tahun itu, mereka melakukan banyak kegiatan backpacking yang awalnya berkaitan dengan unjuk rasa anti perang namun kemudian menemukan jati dirinya dalam bentuk petualangan mencari pengalaman baru di belahan benua Amerika Tengah dan Amerika Selatan. Berbeda dengan rekanrekannya di Eropa yang dapat melakukan perjalanan overland secara murni melintasi benua Eropa-Asia, para backpacker hippies ini terpaksa harus membagi jalur backpacking-nya karena antara Amerika Tengah dan Amerika Selatan terdapat Darien Gap, wilayah yang memutus jalur jalan raya trans Amerika sepanjang ribuan $\mathrm{km}$ tersebut. Jalur itu terpaksa tidak dapat dibangun di wilayah perbatasan Panama dan Columbia karena jenis areanya yang berawa-rawa.

Di Amerika Tengah, jalur yang menjadi daerah tujuan para backpacker ini adalah :

- Meksiko dengan tujuan wisata Isla Mujeres, Tulum, Chichen Itza dan Playa del Carmen. Tulum, Chichen Itza dan Playa del Carmen.

- Nikaragua dengan tujuan wisata di Granada, Leon, San Juan del Sur dan Pulau Ometepe.

- Guatemala dengan tujuan wisata di Tikal, Antigua dan danau Atitlan.

- Belize dengan tujuan wisata great blue hole, gua Ambergris dan gua Caulker.
- Honduras dengan tujuan wisata Pulau Roatan, Utila, Guanaja dan Chayos Chochinos.

- Costa Rica dengan tujuan wisata Puerto Viejo di pinggiran Laut Karibia dan Semenanjung Nicoya dimana terdapat dua pantai indah yang sangat sesuai untuk sunbathing maupun surfing yaitu pantai Playa Tamarindo dan Playa Montezuma.

- Panama dengan tujuan wisata di kepulauan Bocas del toro yang terkenal dengan tempat wisata selamnya.

Sementara itu, untuk Amerika Selatan, jalurnya adalah :

- Ekuador dengan tujuan wisata kepulauan Galapagos dan Montanita.

- Peru dengan tujuan wisata Lima, Cuzco, Iquitos dan situs Indian Inca yang terletak di pegunungan yaitu Machu Pichu.

- Bolivia dengan tujuan wisata di Salar de Uyuni, Potozi, danau Titicaca dan La Paz, ibu kota Bolivia yang terkenal sebagai ibu kota tertinggi di dunia $(3.650 \mathrm{~m}$. di atas permukaan laut).

- Brazil dengan tujuan wisata di Rio de Janeiro, Recife, Salvador de Bahia dan Sao Paolo.

- Argentina dengan tujuan wisata Buenos Aires, Ushuaia dan air terjun Iquazu di perbatasan Brazil.

- Chili dengan tujuan wisata di Pulau Paskah, Pucon dan Torres del Paine.

Oleh para penduduk asli Amerika Tengah dan Amerika Selatan yang mayoritas berbahasa Spanyol, para hippie ini disebut Gringo, kata dalam bahasa Spanyol yang berarti orang asing. Tidak lama kemudian jalur backpacking kaum hippie, baik yang di Amerika 
Tengah maupun Amerika Selatan kemudian lebih dikenal sebagai Gringo Trail.

Jika Gringo Trail dapat bertahan hingga saat ini dan masih ramai denganb para wisatawan (meskipun bukan kaum hippies lagi) tidak demikian yang terjadi dengan Hippie Trail yang melintasi EropaAsia. Jalur tersebut berhenti total pada tahun 1979 akibat adanya Revolusi Iran yang dikobarkan Imam Khomeini yang melarang keras segala bentuk maksiat yang sering dilakukan kaum hippies dan serbuan Uni Soviet terhadap Afghanistan pada tahun yang sama, sehingga bagian penting dari Hippie Trail terutama di wilayah Khyber Pass berubah menjadi medan perang antara pasukan Soviet melawan gerilyawan Mujahidin.

\section{Banana Pancake Trail}

Ketika Perang Vietnam berakhir pada tahun 1976, wilayah Asia Tenggara menjadi destinasi wisata baru bagi para backpacker Eropa dan Amerika. Sebagian besar ingin mengetahui dampak perang tersebut bagi negaranegara sekitar dan sebagian lagi pergi sebagai pelancong biasa. Selayaknya backpacker, mereka juga suka mencoba hal-hal baru dan pergi jauh menjelajah negeri yang mereka kunjungi. Para backpacker di Birma bahkan berkelana sampai Mrauk $U$, suatu kota kuno bekas ibukota Kerajaan Arakan sekitar abad ke 16 yang susah dijangkau. Mereka juga mempopulerkan daerah wisata di Chiang Rai, wilayah Segitiga Emas penghasil opium di perbatasan Thailand, Birma dan Laos yang juga terkenal dengan produksi madunya.

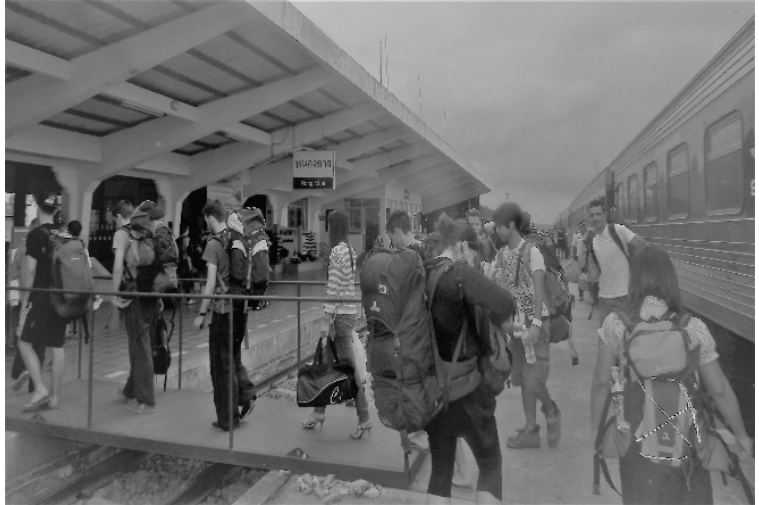

Gambar 11. Para Backpacker di Stasiun Nong Khai, perbatasan antara Laos dan Thailand Sumber : Dokumentasi Penulis

Selalu ada yang unik dalam setiap masa backpacking travel ini, di negaranegara Asia Tenggara yang secara iklim, budaya dan bahasa jelas berbeda dengan negeri asal mereka para backpacker ini menemukan suatu istilah untuk menyebut jalur perjalanan mereka yaitu dengan sebutan Banana Pancake Trail. Sebutan ini berasal dari makanan yang banyak dijajakan di jalan-jalan negara-negara Indo China (Vietnam, Laos dan Kamboja), berupa kue dari tepung dan buah pisang yang diberi topping beraneka macam sesuai dengan pilihan pembeli. Kue pisang ini merupakan kudapan yang sama mudahnya mereka dapatkan di negeri mereka sehingga rasanya tidak asing di lidah, berbeda dengan makanan lainnya khas Asia Tenggara yang biasanya banyak rempah dan kaya akan rasa.

Meskipun "jalur kue pisang” ini sudah terlanjur populer, akan tetapi untuk perjalanan di Indonesia sebutan Banana Pancake Trail kelihatannya kurang sesuai karena jenis makanan tersebut bukan suatu kudapan yang umum di negeri katulistiwa ini. Untuk sebutan backpacking travel di Indonesia mungkin lebih sesuai dengan sebutan "Fried Banana Trail", karena pisang goreng merupakan jenis makanan yang sangat mudah ditemukan di seluruh penjuru negeri ini. 
Berikut ini merupakan jalur wisata para backpacker di Asia Tenggara :

- Thailand; Hatyai-Phuket-KrabiBangkok-Pattaya-Chiang MaiChiang Rai.

- Kamboja; Siem ReapSihanoukville-Pnompenh.

- Laos; Vientiane-Vhang Vieng-Plain of Jars-Luang Prabang.

- Vietnam; Saigon-Hoi An-Hanoi-ha Long Bay.

- Malaysia; Malaka-Kuala LumpurPenang-Sarawak-Sabah.

- Singapura; City Tour

- Myanmar; Yangoon-BaganMandalay-Arakan.

- Philipina; Puerto Princesa-ManilaLuzon.

- Indonesia; Jakarta-BandungYogyakarta-Bromo-Bali-Nusa Tenggara.

Brunei Darussalam dan Timor Leste meskipun termasuk dalam negara Asia Tenggara tetapi belum menjadi tujuan utama para backpacker, hal ini disebabkan karena belum di dukung sepenuhnya sektor pariwisata sebagai salah satu penghasil devisa negara.

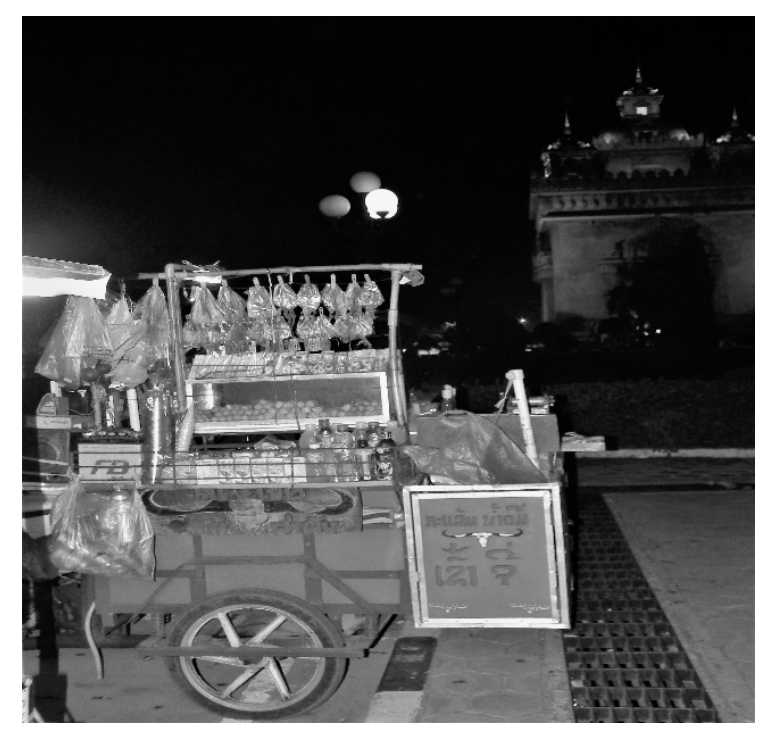

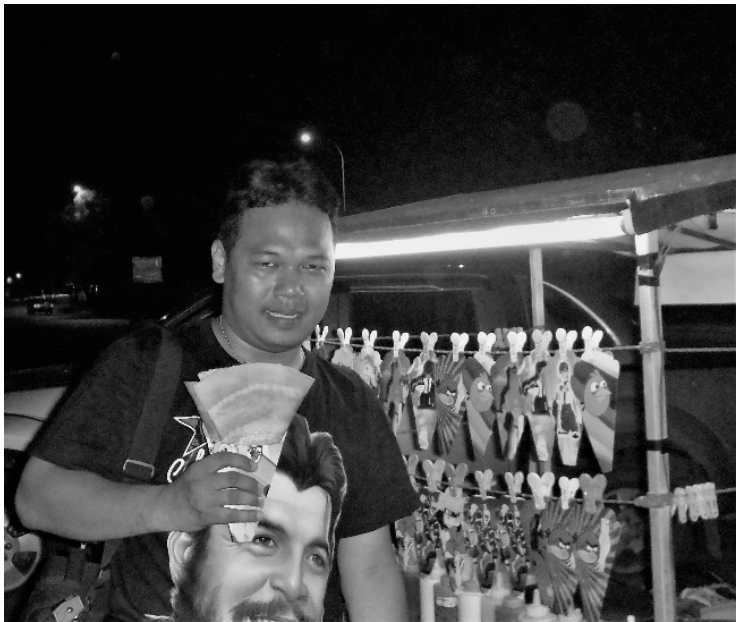

Gambar 12. Backpacker dengan penjual Banana Pancake di depan Monumen Patuxay,

Vientianne, Laos yang merupakan salah satu jalur backpacking travel yang fenomenal di kawasan Asia Tengggara.

Sumber: Dokumentasi penulis

\section{E. Karakter Backpacker}

Memperhatikan perjalanan backpacking travel dari masa ke masa dapat ditemukan beraneka macam karakter dari para pelakunya, yaitu :

1. Karakter Umum :

- Backpacker adalah budget traveler, mereka adalah pelaku perjalanan yang sangat peduli dengan pemakaian anggaran, tidak selalu harus hemat tetapi setiap pengeluaran selalu dapat dipertanggungjawabkan.

- Memiliki hasrat untuk bertualang.

- Memiliki keinginan kuat, tidak hanya untuk menemukan atau mendapatkan pengalaman baru akan tetapi juga untuk berbaur dengan masyarakat setempat dan para backpacker lain dari negara yang bebeda.

- Terorganisir secara independen dan memiliki jadwal yang fleksibel.

- Melakukan perjalanan lebih lama dan lebih jauh daripada sekedar liburan wisata. 
- Sebagian besar dilakukan oleh mereka yang masih berusia muda.

- Didominasi oleh mereka yang memiliki pendidikan cukup baik (well educated).

- Peduli terhadap isu-isu lingkungan dan sangat tertarik dengan ekowisata.

- Sebisa mungkin menggunakan kendaraan umum.

- Bersedia melakukan pekerjaan di negara tujuan untuk menunjang perjalanan maupun menambah pengalamannya.

2. Karakter Khusus :

Karakter khusus backpacker dapat dibagi dalam beberapa katagori, yaitu:

- Berdasarkan motivasinya :

- Explorer backpacker, yaitu mereka yang melakukan perjalanan dengan tujuan untuk mengeksplorasi daerah-daerah yang belum dikenal, baik untuk kepentingan kemajuan ilmu pengetahuan maupun kemuliaan pribadi, bangsa dan negara.

- Adventure backpacker, hampir sama dengan explorer backpacker akan tetapi lebih mengutamakan nilai petualangannya, biasanya mereka menjangkau tempat yang jelas diketahui sudah ada dalam peta.

- Independent Backpacker, yaitu para backpacker yang melakukan perjalanannya sekedar untuk merasakan nuansa yang berbeda dengan tempat tinggalnya atau pengalaman baru di negara lain. la seringkali memutuskan jadwal dan tempat yang akan ia kunjungi pada saat sudah sampai di negara tujuan.

- Berdasarkan jumlahnya :
- Individual Backpacker, yaitu mereka yang melakukan perjalanan sendirian.

- Group Backpacker, yaitu mereka yang melakukan perjalanan dalam kelompok, baik kecil maupun besar.

- Berdasarkan sifatnya :

- Conservative Backpacker, yaitu mereka yang melakukan perjalanan sesuai dengan itinerary yang telah direncanakan sebelumnya dari negara asal. Meskipun ada kemungkinan perubahan sifatnya minor.

- Freelance Backpacker, yaitu mereka yang melakukan perjalanan sesuai dengan situasi dan kondisi terkini negara tujuan dan juga anggaran mereka. Seringkali membuat perubahan dalam itinerary-nya.

- Berdasarkan tujuan perjalanannya :

- Domestic backpacker, yaitu mereka yang melakukan perjalanan di negaranya sendiri.

- International backpacker, yaitu mereka yang melakukan perjalanan di negara lain (cross border/antar negara).

- Berdasarkan pembiayaan :

- Own Budget backpacker, yaitu mereka yang membiayai sendiri perjalanannya.

- Sponsorship backpacker, yaitu yang mengandalkan dukungan sponsor (baik swasta maupun pemerintah) untuk pembiayaan perjalanan mereka.

Karakter-karakter yang tersebut di atas tentu masih dapat diperdebatkan karena seiring perkembangan jaman, apalagi dengan munculnya versi-versi backpacker yang baru seperti flashpacker, yaitu para backpacker yang 
memiliki keleluasaan tidak hanya dalam waktu tetapi juga masalah biaya. Selanjutnya adalah technopacker, yaitu para backpacker yang sangat mengandalkan perangkat teknologi informasi dan komunikasi dalam melakukan perjalanan mereka dan memiliki karakter tersendiri karena sangat familiar dengan gawai. Terdapat juga para pelaku perjalanan petualangan ini yang sekaligus menulis daya tarik apapun yang ditemuinya selama perjalanan (terutama pariwisata) dan di muat dalam jurnal, blog, web, majalah, surat kabar bahkan dengan kemajuan teknologi internet saat ini yang memungkinkan streaming video secara langsung dapat ditampilkan di media audio visual yang populer disebut travel writer.

\section{KESIMPULAN}

Terdapat suatu hal yang menarik dalam paradigma historis mengenai fenomena backpacker dan backpacking travel yang dapat disimpulkan dengan betapa dinamisnya pola perjalanan dan karakter mereka selama melakukan perjalanan tersebut, dimana semangat backpacker adalah selalu berusaha untuk melakukan perjalanan lebih lama, lebih jauh daripada wisatawan pada umumnya. Mereka juga menghormati budaya lokal, membeli barang kebutuhan dari masyarakat setempat, ikut serta melindungi warisan sejarah, hemat energi dan sebisa mungkin memanfaatkan setiap perjalanan mereka dengan ikut beradaptasi dan berinteraksi dengan penduduk lokal.

Fenomena backpacking travel merupakan warna tersendiri dalam sejarah pariwisata dunia. Karena bagaimanapun backpacking travel sebenarnya adalah pola pikir yang diaplikasikan dalam suatu perjalanan. Sebagai suatu gaya hidup backpacking travel memperindah khasanah yang sudah ada dan mendobrak pola perjalanan wisata kontemporer. Backpacking travel di masa depan, sangat mungkin memberikan pengaruh besar dan akan menjadi salah satu penggerak utama kegiatan pariwisata di seluruh penjuru dunia.

\section{DAFTAR PUSTAKA}

Barnes, I. (2008) Mapping History Ancient World, Cartographica Books, London UK.

Berger, E.A., Paris, C.M. (2013) Exploring the Influence of Facebook on Backpacker's Social Experience in Hostels, Review of Tourism research Vol. 10 No. 5/6, 2013.

Bleach, S. and Schofield, B. (2004) Time to Go Backpacking in Style, 31 October The Times Online.

Bradt, H. (1995) Better to Travel Cheapy?, The Independent on Sunday Magazine, 12 February, 49-50.

Brooks, Philips., Will Fowler \& Simon Adams (Ed) (2009). The Illustrated History Encyclopedia, Hermes House, London UK.

Canning, J. (Ed) (2003). 50 Great Journeys, Bounty Books, London UK.

Clifford, J. (1997) Routes: Travel and Translation in The Late Twentieth Century, Harvard University Press, Massachusets, USA.

Cochrane, J. (2005) The Backpacker Plus: Overlooked and Underrated, Paper read at the ATLAS Expert meeting, Bangkok, September.

Cottrell, S. (2001) A Dutch International Development Approach: Sustainable Tourism.

Cohen, E. (1973) Nomads from Affluence: Notes on the Phenomenon of Drifter Tourism, International Journal of Comparative Sociology. 
Cresswell, T. (2006) On The Move : Mobility in The Modern western World, Routledge, London UK.

Deleuze, G. And Guattari, F. (1988) A Thousand Plateaus, The Athlone Press, London UK.

Gilroy, P. (1993) The Black Atlantic : Modernity and Double Consciousness, Verso, London UK. Government of Australia (1995) National Backpacker Tourism Strategy, Australian Government Publishing Service, Canberra, Australia.

Johnson, P. (2004), A History of The American People, Phoenix Press, London UK.

Hampton, M.P. (1998) Backpacker Tourism and Economic Development, Annals of Tourism Research 25 (3) 639-660)

Hampton, M., Hamzah, A. (2010) The Changing Geographies of Backpacker Tourism in South East Asia, University of Kent, UK.

Hannam, K. And Ateljevic, I. (Eds) (2007) Backpacker Tourism, Clevedon.

Hannam, K. and Ateljevic, I (2008) Backpacker Tourism: Concepts and Profiles, Tourism Cultural Change, Channel View Publications, Bristol, Buffalo, Toronto, Canada.

Howard, R.W. (2007) Five Backpacker Tourist Enclaves, International Journal of Tourism research 9 (2) 73-86.

Loker-Murphy, L., and Pearce, P. (1995) Young Budget Traveller: Backpackers in Australia, Annals of Tourism Research 22 (4) 819843.

Majstorovic, V., Stankov, U., Stojanov, S. (2013) The Presence of Backpacking in Europe, Turizam Vol. 17 Issue 4.

Murphy, L. (2000) All Backpackers are not alike! Segmenting the backpacker Market Based on Differences in
Travel Motivation, Tourism Discussion Paper, February, Cairns: James Cook University, Australia.

Vaals, F.V. (2013) The Future of Backpacking: A Scenario Approach to the backpacking Behavior, European Tourism Report 7, European Tourism Futures Institute, Netherlands.

Pearce, P. (1990) The Backpacker Phenomenon: Preliminary Answers to Basic Questions, Townsville: Department of Tourism, James Cook University, Australia.

Reichel, A., Fuchs, G.and Uriely, N. (2009) Israeli Backpackers: The Role of Destination Choice, Annals of Tourism research, 36 (2) 222246.

Richards, G., Wilson, J. (2004) The Global Nomad: Backpacker Travel in Theory and Practice, Tourism and Cultural Change, Channel View Publications, Bristol, Buffalo, Toronto, Canada.

Riley, P. (1988) Road Culture of International Long-Term Budget Travellers, Annals of Tourism Research 15: 313-328.

Rodaway, P. (1994) Sensuous Geographies : Body, Sense and Place, Routledge, London UK.

Rogerson, C. (2007) The Challenges of Developing Bcakpacker Tourism in South Africa: an Enterprise Perspective, Development South Africa 24 (3) 425-443.

Sheller, M. And Urry, J. (2004) Tourism Mobilities : Places To Play, Places in Play, Routledge, London UK.

Sicroff, S., Alos, E., and Shrestha, R. (2003) Independent Backpacker Tourism: Key to Sustainable Development in Remote Mountain Destination, Pages 527-543 in J. Xu and S. Mikesell, Eds. Landscape of 
Diversity: Indigenous Knowledge, Sustainabele Livelihoods, and Resource Governance in Montane mainland Southeast asia. Proceedings of The III Symposium on MMSEA, Science and Technology Press, Lijiang, China.

The Kingfisher History Encyclopedia, Kingfisher, London UK, 2012

Teo, P. and Leong, S. (2006) A Postcolonial Analysis of Backpacking, Annals of Tourism research 33 (1) 109-131.

UNWTO Annual Report 2013

Visser, G. (2004) The Development Impacts of Backpacker Tourism in South Africa, Geo Journal 60: 283299.
Vogt, J. (1976) Wandering: Youth and Travel Behavior, Annals of Tourism research 4 (2) 74-105)

Welk, P. (2004) The Beaten Track: AntiTourism as an element of Backpacker identity Construction. The Global Nomad: backpacker Travel in Theory and practice, Tourism and Cultural Change, Channel View Publications, Bristol, Buffalo, Toronto, Canada. www.nomadsworld.com 